\title{
Effective Leadership Qualities of Distance Education in Globalization
}

\author{
${ }^{1}$ Mian Baqar Qureshi, ${ }^{2}$ Nuzhat Kalsoom Shahzadi, ${ }^{3}$ Zubia Noreen \\ PhD scholar, AIOU, Islamabad Pakistan
}

\begin{abstract}
Leadership in Distance education not only requires common characteristics of all leaders, but also requires exceptional aptitudes and approaches under the impact of emerging technologies. This is the fact that people do not get distance education as different from conventional education in terms of leadership and the reason is lack of specific qualities in distance education leadership.

Leadership is one of numerous vital components in the successful addition of ICTs in Education. The locus of leadership influences the scale to which ICT integration can become fixed in educational institutions as well as the role of leadership in championing ICT. There are many challenges inbuilt in enlightening circulated leadership in and across educational institutions. The effectual utilizations of technology to connect educational leaders at all levels in collaborative learning and knowledge sharing can improve leadership capacity which can add the successful integration of ICTs in Education. It is a review study so data and information is collected through literature relevant to distance education, leadership in education and quality education. Data was collected by book reading and net searching.
\end{abstract}

Keywords: distance learning, higher education, distance learners, Internet, leadership, ODL, technology, ICT, methodology,

\section{Introduction}

Open and distance learning as part of higher education, plays essential role for community and economic revolution. It is fundamental source of HRD globally. It is tough to choose what exactly constitutes the quality of education. There are different people who have different perspectives about the quality. We see two aspects of quality in the learning point of view; one is quality of the system as one unit and secondly quality of any system, offers to the learners.

The objective of this paper is to present a descriptive review of studies on the citing scholarly literature related to ICT, distance learning and leadership. This paper searches for answers the questions;

(1) What does meaning of quality in distance education?

(2) What is the scope of distance education leadership?

(3) How distance education leadership is different from the formal or conventional leadership?

Distance educators know the attitude of formal learning where quality deals with diverse factors of "face-to-face" education like the infrastructure as well as essential services, social and geographical milieu, instructional professional ability, organizational and investment staff, appraisal of the teachers, students, teaching methodology, the public support to the organization, performance fitness and worth of curriculum,. However, ODL is different from formal education. Distance learner has different profile. The major goal of higher education through the distance education is always different from formal education.

While investing for ICTs in education, policy-makers often have incompatible objectives. At times, the emphasis is on training computer skills and knowledge, now emphasis is on improving the quality of education. Learners are given access to a wider range of resources than they could otherwise enjoy, or teaching in a more operational way because ICT is the way to save money. They want to reach more people without increase in costs as improving the productivity of the education system. They want to broadening access, to range learners such as the isolated at a lower cost than would otherwise be demanded. In adding more, ICTs are sometimes perceived as a way to expand the time limit of education and training. Even then it seems difficult to meet all these objectives at the same time with a particular instrument.

"If ICTs can be used effectively to improve the delivery of education, they offer worthwhile prizes: in particular, lower costs and wider access. But policy-makers increasingly want to see value for money and clear evidence that educational investments will deliver commensurate benefits. And some of the early enthusiasts for 
ICTs in education have become more cautious, or even downright skeptical. This paper examines the conditions that need to be met if ICTs are to improve the delivery of education sufficiently to justify the investment involved. Where those conditions are not met, educators may do better to stick to the age-old recipe of "chalk and talk". (http://www.itu.int/osg/spu/visions/papers/educationpaper.pdf[1])

\section{Qualities in Education}

The definition of Quality is "embracing effectiveness, efficiency and accountability.

These terms, however, have connotations with terms used in trade, commerce and industry" (www.openpraxis.com[2]). Education is much different in every component, in particular, within "input, process and output",. Education is pure energy to grow into "learned". Education is a way to flourish in individual life and acquire sophisticated values.

It show needs and desires of the receivers. Therefore "excellence in higher education" is defined as "fitness for the purpose". But this is somewhat an exclusive criterion.

\section{Use of Quality in ODL}

Open distance learning eliminates obstacles in accessing "admission pre-requisites, physical attendance at a particular place and time, possession of prescribed equipment, books, journals, and so on. Distance learning means that the learners are physically separated in space and time from the teaching institution and its staff'( Gandhe,S.K(2009) [2])

An extraordinary quality of Open Learning is, apply well-tried ideology for allotment of industry, narrowing down its working methodically and self determinedly, as compare to formal system. There are five zones to whom quality concerns and these areas need to be dynamically applied to the "elements of ODL to guarantee that no element lacks the probable degree of quality:

- Curriculum design, content and organization

- Teaching, learning and assessment

- Student progression and assessment

- Student support and guidance"

(Gandhe,S.K, 2009 [2])

The inner quality assurance mechanism, assessment by peers, accreditation by self-governing and proficient organization are three approaches of quality education. Virtuous and serious ODL institutions always guarantee that these approaches are adopted to ensure the top quality in every field of distance education.

Quality as concept is not easy to understand. Quality expresses achievements of the probable levels of knowledge and skills, in the ODL system. These skills are used as tools for further learning. In ODL system work experience is needed for handling the student's individual and societal matter in daily life and quality of education, keeping in view their time-frame.

Defining quality in relation to education is difficult. We see education has two important features of quality; one is quality as a unit system and second is quality of the system offered to the distance students.

We see an important development in distance leadership that distance learners has interest and attitude towards publishing more researches, articles and documents about the leadership of distance education. The "International Center for Distance Learning (ICDL)", "Distance Education Library" and the "Educational Resources Information Center (ERIC)" only control hundreds of such documents. The majority of documents are examine distance education policies and strategies, organizational management, student support systems and learners management related to all generations of distance education. First three generations are important for delivery models and they are correspondence, multimedia and tele-learning. It's amazing; these generations have not noted about the academic leadership connected with distance education as much as essential. So for the better quality of future leadership in distance learning needs to be examined more and more. Because it seems clearly that leadership in distance education will become necessity of the time.

\section{Scope of ICT in Education and Leadership}

Many researchers have supported the role ICT in education and leadership"Leadership establishes a culture that enables innovation as well as a shared sense of responsibility for innovation" (Kirkland \& Sutch, 2009[3]) 


\subsection{Accessibility}

"Facilitate easy and quick access to ICT-rich teaching and learning resources including ICT systems and services, computing resources, online learning materials, e-Learning and other education centered applications". (http://www.ungaid.org/tabid/885/Default.aspx [4])

The main function of ICT is planning. Online resources including e-learning, digital libraries, establishing of information hubs and open content communities, agenda for amplified broadband connectivity, easy access to open resources need to be increased.

\subsection{Empowerment}

"Empower educational communities with ICT technologies and continuously upgrade their ICT-driven teaching and learning skills". (http://www.un-gaid.org/tabid/885/Default.aspx[4]). It helps to make strategies for increasing digital aids for easier access and better training of team members between educational groups and instructional designers. .

\subsection{E-Learning}

Adoption of web and increasing use of internet in learning is become emerging trend. Internet and web based learning enable broaden access to learning. It also helps in refining learning activities made the e-learning more useful. It also provides guidelines, frameworks e-learning practices. The qualities of e-learning are

"initiatives for promoting learning and educational technologies research ,Awareness sessions and events on eLearning content development, use of learning management systems (LMS) and content management systems (CMS) ,e-Learning centers of excellence for sharing/exchanging eLearning content, development tools, professional expertise and experience and Sharing professional development resources" (http://www.un-gaid.org/tabid/885/Default.aspx [4])

\subsection{Healthy Learning Atmosphere}

Technology facilitates the establishment of constant, healthy, safe and effectual ICT based environment. ICT support its availability and reliability of learning activities. ICT provides resources for mobile learning and remote learning. ICT support the learners to make sound learning environments and knowledge societies, high-tech atmosphere in educational organizations. Their public based support and sharing of resource, using "smart computing facilities" and laptops, all are due to these leading approaches of ICT.

\section{5 e-Learning and e-teaching methodologies}

Technology also improves e-teaching methodologies using of ICT. These technologies support learning objectives and teaching instruments for distance education with international cooperation. Web-based learning, and online teaching methodologies through "skill development" and "capacity building programs" all are backing it more strongly.

\subsection{Lifelong learning}

A leader learns throw out his life. Continuous education develops a framework for web enabled alltime learning for distance leaders. E-Training used for allow all-time learning and making networks between theoretical learning and experimental learning. Getting desired learning and training for personal and professional improvement through e-learning is easier.

\subsection{Research and Innovation}

ICT encourages applied research and advanced forms of education. This development promotes culture of innovation. The process of learning in favor of interdisciplinary research groups help to create focused curriculum resources, expert, learning stuffs, test items, support resources, groups of experts. And these researches and innovative work help to lead for solution of issues.

\subsection{Policy}

The progress for development of authorized policy, and regulatory frameworks to encourage learning desires and utilize funds in the field of education. Here ICT protects "intellectual property" and motivate 
modernization to policy, and legislative regulatory framework for learning. Distance leaders follow updated policies and plan.

\subsection{Broadcasting Education}

The role of World Wide Web is to provide online forums, publications, and free space for ICT investors, broadcast gathered information, experiences, and services. Web publishes documents and information for distance learners. "Virtual exhibition" of famous ICT products and services on education are available easily. These publications, discussion forums, news, and advertisements enable leaders for collaborative and better work.

\subsection{Continuity of development:}

Rapid changes in technology enhance to take continuous steps of development. This continuity reproduces knowledge for continuing struggle on ICTs to meet new demands. Impact of these efforts on ICTs in education adds to constant pace of development and its assessment. An effective leader should have all the knowledge of all development.

\section{DistanceEducationLeadership}

Distance education leadership plays a vital role for all ages. In distance education leadership, more researches on specific types of leadership are required. "A reasonable amount of attention has been given to the planning and administration of distance education for quite some time" (Beaudoin, 2002 [2]). This might be measured satisfactory enough without arguing the more area of leadership that are still hidden.

Lee (2001) giving argument,

"Although the organizational behavior theorists and researchers have investigated perceived organizational support in many different organizational environments, higher education institutions have rarely been examined. Yet, no studies have investigated the perceptions of faculty with regard to instructional support, and whether their perceived organizational support has a relationship to faculty motivation, commitment, and satisfaction in relation to distance technology". (www.associatedcontent.com [5])

As Beaudoin (2002)[6] said, "leadership is not widely recognized as distance education has been based both on traditional education leadership and business/industry leadership." Pahal (1999) [7] stating, "IT leadership requires many of the characteristics common to all leaders, but also requires special abilities and insights into technology's impact." Nominal role of distance education leadership might be due to the fact that distance education is different from formal education in the training of future generations. Both in formal and distance education institutes unite in term of better educating people. Leaders is person who deals with latest programs offered by his institution on exclusive lines. A courageous and innovative leadership is required to achieve and appraise these developing new trends and formats, focused on huge amount by networking technology and emergingmethods.

"Some people see the leader as a motivator, while others define a leader as one having extraordinary vision and decision-making power (Pahal, 1999 [7])

Beaudoin (2002) [6] points out some characteristics that "a distance education leader needs to

(1) create conditions for innovative change,

(2) enable individuals and organizations to share a vision and move in its direction, and

(3) contribute to the management and operationalization of ideas."

These characters are understood in transformational leadership. The method of applying and utilizing these characteristics is exceptional for the distance education leader. Become an effective Leaders do not overnight work. An effective leader has long time to bring change. He becomes capable to move large number of staff in the same positive direction after hard struggle. Formal and traditional academics are different. But Leaders in traditional academic circles and online academic circles perform same type of responsibilities

Distance education leaders have to perform as situational leaders. Distance education leader as situational leader identify the issues of institute at a specific moment and determine the readiness to solve them for sake of organization and leaners benefits. "The IT leader must be a self-achiever and should be motivated to 
become a proactive leader and role model. Changes in technology often produce a 'chaos situation' where change management in the use of instructional technology in teaching and learning becomes increasingly important. The IT leader must be ready to embrace that change."( Pahal, 1999 [7])

But we cannot ignore human factors in planning and designing technical materials. Leading person require more planning than technical design to enlist user acceptance and create a sustained use of the application.

"The introduction of distance learning by an influential person prior to use is important for adoption and successful implementation. By being aware of change, and open to change, the leader in distance education is more likely to (1) recognize a need for change at any given moment, (2) acknowledge the probable reactions of the constituents towards change, and (3) react appropriately to the responses to the proposed changes."( http://voices.yahoo.com/leadership-distance-education-11237.html [8])

Many researchers and authors have given their views on skills and steps of effective leaderships. It is impotent to discuss about the skills that distance teachers or tutors or instructors need as leader. We found different opinion as table1 show that planning, implementation, resources and support system are important.

Table 1: Comparison of Categories and Authors' Descriptions

\begin{tabular}{|c|c|c|c|c|}
\hline $\begin{array}{l}\text { Leadership } \\
\text { Categories }\end{array}$ & \begin{tabular}{|l|} 
American \\
Council on \\
Education
\end{tabular} & Bates & Kovel-Jarboe & Lape and Hart \\
\hline Planning & $\begin{array}{l}\text { Policies } \\
\text { incorporate } \\
\text { needs of } \\
\text { distance } \\
\text { education }\end{array}$ & $\begin{array}{l}\text { - Leadership, } \\
\text { vision and (Newe } \\
\text { planning (New } \\
\text { technology is } \\
\text { accompanied by } \\
\text { major change. } \\
\text { - Management } \\
\text { (Administrative } \\
\text { and academic } \\
\text { policies). }\end{array}$ & 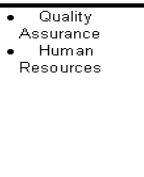 & $\begin{array}{l}\text { Planning } \\
\text { Factors leading } \\
\text { to adoption of } \\
\text { distance education } \\
\text { \& technologies; } \\
\text { identify barriers } \\
\text { Organizational } \\
\text { and instructional } \\
\text { changes }\end{array}$ \\
\hline Implementation & $\begin{array}{l}\text { Overall mission } \\
\text { compatible with } \\
\text { provider }\end{array}$ & $\begin{array}{l}\text { Curriculum (Use of } \\
\text { technology } \\
\text { embedded with } \\
\text { wider strategy for } \\
\text { teaching/ le arning) }\end{array}$ & $\begin{array}{l}\text { Governance, } \\
\text { mission, and } \\
\text { programs }\end{array}$ & $\begin{array}{l}\text { Mission and } \\
\text { policies } \\
\text { Curriculum } \\
\text { issues; changes in } \\
\text { teaching/learning } \\
\text { strategies }\end{array}$ \\
\hline Resources & $\begin{array}{l}\text { Financial and } \\
\text { administrative } \\
\text { commitment }\end{array}$ & $\begin{array}{l}\text { - Funding } \\
\text { - Technology } \\
\text { Infrastructure } \\
\text { - Faculty support }\end{array}$ & $\begin{array}{l}\text { - Financial } \\
\text { - Infrastructure }\end{array}$ & Costs \\
\hline Support & $\begin{array}{l}\text { Administrative } \\
\text { and support } \\
\text { systems } \\
\text { compatible with } \\
\text { delivery systems }\end{array}$ & & Student Support & \\
\hline
\end{tabular}

Source: Irlbeck(2002) http://www.irrodl.org/[9]

This is not enough; teacher of distance education has much more responsibilities. Table2 shows characteristics of teacher when he playing the role of leader. Distance education leader is not only teacher, facilitator, mediator, psychologist, motivator, planner, but he plays other dynamic roles.

\section{Table 2 Distance Education Teacher as a Leader Model}

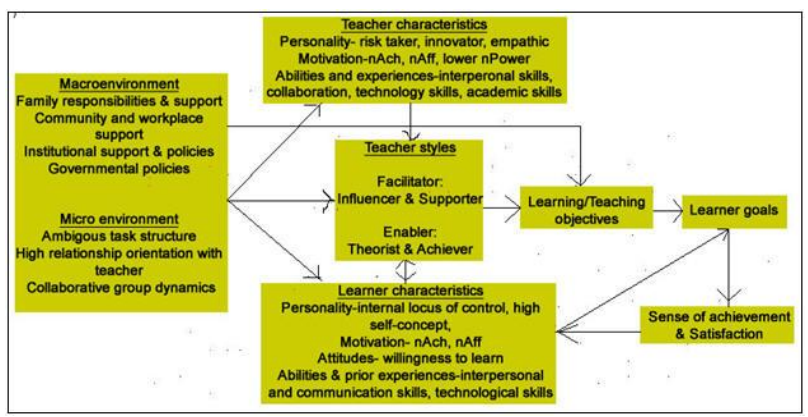

Source: Dewan, S,(2010) http://jolt.merlot.org/vol6no3/dewan_0910.htm [10]

Moreover, a distance education leader needs to adopt systemic leadership.

"Leadership also involves creating steppingstones that bridge from a desired future to the current gridlock typical of many American schools. In evolving from its present state to a distant objective, an educational 
institution must progress stage by stage. Each step of evolution requires a critical mass of resources and must create a stable, desirable situation."( Lee, 2001[5])

Leadership also perceives the "process of social influence in which one person can enlist the aid and support of others in the accomplishment of a common task ".( Chemers M. 1997 [11])

"Organizing a group of people to achieve a common goal" is leadership.it is not sure that leader may have any formal authority. Leadership has theories involving qualities like, "situational interaction, function, behavior, power, vision and values", (Richards \& Engle, 1986[12]

"Leadership is not so much about technique and methods as it is about opening the heart. Leadership is about inspiration - of oneself and of others. Great leadership is about human experiences, not processes. Leadership is not a formula or a program, it is a human activity that comes from the heart and considers the hearts of others. It is an attitude, not a routine".( Lance Secretan,1998)http://www.heartquotes.net/Leadership.html [13])

"Leadership is not magnetic personality - that can just as well be a glib tongue. It is not "making friends and influencing people" - that is flattery. Leadership is lifting a person's vision to higher sights, the raising of a person's performance to a higher standard, the building of a personality beyond its normal limitations." (Peter F. Drucker [14])

For effective leaders, skills of leadership and learning both are required. Because leadership and learning are necessary to each other. Handbook on military leadership argues that effective leaders grow among the never-ending procedure of self-study, training, and expertise.

In past emerging methods and measurements were adopted after great studies. Many significant reviews finally restore the quality theory as a practical approach for leadership. "For example, improvements in researchers' use of the round robin research design methodology allowed researchers to see that individuals can and do emerge as leaders across a variety of situations and tasks". (Kenny, D.A. \& Zaccaro, S.J. 1983 [15]) During 1980s statistical progresses permitted researchers to study meta-analyses. They could quantitatively analyze and summarize the findings from a wide array of studies.

Though the quality of leadership has positively recovered its reputation and has not been go along with corresponding growth in classy theoretical contexts for the students of leadership.

Precisely, Zaccaro (2007) gives views about quality theories.

- "focus on a small set of individual attributes such as Big Five personality traits, to the neglect of cognitive abilities, motives, values, social skills, expertise, and problem-solving skills;

- fail to consider patterns or integrations of multiple attributes;

- do not distinguish between those leader attributes that are generally not malleable over time and those that are shaped by, and bound to, situational influences;

- Do not consider how stable leader attributes account for the behavioral diversity necessary for effective leadership".( Zaccaro, 2007[16])

This is also true that online learning gains better recognition. Surly it will gain more height as unit that represents high quality education opportunities to students no matter where they are located and leads nations towards better learning. "Transforming an organization also requires a new vision, new frames for thinking about strategy, structure, and people. While some... can start with a clean slate, transformational leaders must begin with what is already in place."( Tichy (1986 [17]) Now there is paradigm shift from the old leadership model toward a new electronic vision, integrating latest technologies and establishing the organizations, policies and other supports services for distance education programs. This is the role that transformational leaders of all mode of education must play in our colleges and universities. 


\section{Conclusion:}

In this study it is concluded after reviewing many researches and publications that distance education leaders, their characteristics, their requirements, need for latest technology and their performance as effective distance education leader still not been sufficiently explored. We as distance educators have still need to explore more knowledge to get satisfactory definition of these aspects of an effective and qualitative distance education leadership. Researchers of this study hoped to bring the views and opinion of various researchers together to help future distance education leaders. They tried for the best placement of leadership dynamics for enhancing the distance education vision more effectively. Here we need all type of leadership and even need to explore more vistas for future learners which help them to lead them globally.

Quality expresses achievements of the probable levels of knowledge and skills, in the ODL system.

Undoubtedly ICTs are financial tool both for managing teaching. Use of ICT in managing educational institutions should be encouraged. Effective use by instructors to get advance access towards qualitative educational materials is valuable. Attaining the best from ICTs depends on many variables. These variables included appropriate design of software and hardware, the training and attitude of tutors, and the understanding that different students have different requirements. Effective leadership qualities of distance education depend on Learner's willingness to experiment. Effective leadership have complete understanding about the use of ICTs in learning and training, which is likely to require quite different pedagogical techniques from traditional classroom teaching because takes a long time to develop and broadcast education with cost-effectiveness innovation.

Well-made ICTs can permit Distance Education Leaders to reach new groups of potential group of students, particularly mature students, lifelong learners, and students with physical disabilities, students in employment and students who are far from education centers. Mostly these groups are composed mainly of adult and well-motivated learners. In developing countries digital divide made the learners isolated. But electronically delivered courses may make the difference for all people in remote rural areas. . Only the need is to utilize all funds and resources effectively. In developing countries ICT is helpful for researchers and administrators. Many education policy-makers seriously underestimate the total costs of operating ICT-based learning.

It should remember that technology is never a substitute for good leadership. Electronic delivery and achievement of good results are due to only a skilled instructor. A skilled instructor in both systems traditional and distance can use ICTs for creating quality leadership characteristics.

It is recommended that distance institution specialists of ICTs, who are interested to support education toward betterment and innovations may encourage for investment. Distance Education institutions which are interested in providing open content, policy making are may encouraged for educational development, Funding agencies may take interest in program development academics. Researchers who are doing research in ICTs for educational leadership may enhance more effective qualities the benefits of future leaders.

This study recommends for building centers of excellence in ICTs in education as sources of expertise in leadership. These centers will also helpful for Developing and maintaining an online support of educational products, material, expert groups, and support information. By teaching computer skills to youngsters, they may influence inward investment for producing quality education.

[2] Gandhe,S.K(2009), QUALITY ASSURANCE IN OPEN AND DISTANCE LEARNING IN INDIA, Symbiosis Center for Distance Learning , India http://www.openpraxis.com/files/Gandhe\%20et\%20al..pdf

[3] Kirkland, K., \& Sutch, D. (2009). Overcoming the barriers to educational innovation, A literature Review. Bristol: Futurelab.

[4] http://www.un-gaid.org/tabid/885/Default.aspx

[5] Lee,J. (2001). Instructional support for distance education and faculty, motivation, commitment, satisfaction. British Journal of Educational Technology 32 (2), 153-160

[6] Beaudoin, M. (2002). The Instructor's Changing Role in Distance Education. The American Journal of Distance Education 4(2) p. 131-144.

[7] Pahal, D. (1999, Summer). Effective leadership - An IT perspective. Online Journal of Distance Learning Administration II (II)

[9] Irlbeck,S.A(2002), leadership and distance education in higher education: Aus perspective university of Minnesota, Vol3, No2(2002)http://www.irrodl.org/index.php/irrodl/article/view/91/170 
IOSR Journal of Business and Management (IOSRJBM)

ISSN: 2278-487X Volume 1, Issue 2 (May-June 2012), PP 40-47

www.iosrjournals.org

[10] Dewan, S, (2010), distance educationa teacher as a leader: learning from the path goal leadership theory. Journal of online learning and teaching, vol6 no3, September 2010. http://jolt.merlot.org/vol6no3/dewan_0910.htm

[11] Chemers M. (1997) An integrative theory of leadership. Lawrence Erlbaum Associates, Publishers. ISBN 9780805826791)

[12] Richards \& Engle, 1986, p.206

[13] http://www.heartquotes.net/Leadership.html

[14] Drucker, P. F. (1998). The Age of Social Transformation. In G. R. Hickman (Ed.) Leading Organizations: Perspectives for a New Era (p. 538-556). Thousand Oaks, CA.: SAGE Publications.

[15] Kenny, D.A. \& Zaccaro, S.J. (1983). An estimate of variance due to traits in leadership. Journal of Applied Psychology, 68, 678685

[16] Zaccaro, S. J. (2007). Trait-based perspectives of leadership. American Psychologist, 62, 6-16.

[17] Tichy, N. M., and Devanna, M. A. (1986). The Transformational Leader. New York: John Wiley and Sons. 